Article

\title{
Using Seasonal Forecast as an Adaptation Strategy: Gender Differential Impact on Yield and Income in Senegal
}

\author{
Ndeye Seynabou Diouf *, Mathieu Ouedraogo $®$, Issa Ouedraogo $®$, Gnalenba Ablouka and \\ Robert Zougmoré \\ The CGIAR Research Program on Climate Change, Agriculture and Food Security (CCAFS), \\ ICRISAT West \& Central Africa Regional Office, Bamako BP 320, Mali; M.ouedraogo@cgiar.org (M.O.); \\ i.ouedraogo@cgiar.org (I.O.); gnalenbaablouka@gmail.com (G.A.); R.Zougmore@cgiar.org (R.Z.) \\ * Correspondence: S.Diouf@cgiar.org; Tel.: +223-221-775-320-427
}

Received: 11 August 2020; Accepted: 28 September 2020; Published: 20 October 2020

\begin{abstract}
The use of seasonal forecast has been demonstrated as a good option to reduce the effects of climate variability in sub-Saharan African countries. However, its use, benefits and interests may be different depending on gender. This paper aims at analyzing the gender differential impact of the use of seasonal forecast on the main crop yields (rice, maize, sorghum, millet and groundnut) and farm income in Senegal. We collected data from 1481 farmers (44\% women) in four regions of Senegal. We applied the counterfactual outcomes framework of modern evaluation theory to estimate the local average treatment effect (LATE) of the use of the seasonal forecast on crop yield and farm income. The results showed a significant impact of the use of the seasonal forecast (SF) in the main crop yields and the agricultural income for farmers in Senegal. This impact varies according to the sex and the type of the crops. The users (men and women) of the seasonal forecast gained on average $158 \mathrm{~kg} / \mathrm{ha}$ and $140 \mathrm{~kg} / \mathrm{ha}$ more yield than the non-users, respectively, for millet and rice crops. The impact of the use of SF is greater for men on millet $(202.7 \mathrm{~kg} / \mathrm{ha} \mathrm{vs.} 16.7 \mathrm{~kg} / \mathrm{ha})$ and rice $(321.33 \mathrm{~kg} / \mathrm{ha} \mathrm{vs.}-25.3 \mathrm{~kg} / \mathrm{ha})$. However, it is greater for women on maize $(210 \mathrm{~kg} / \mathrm{ha} \mathrm{vs.}-105 \mathrm{~kg} / \mathrm{ha})$. Potential users of seasonal forecast had also a positive and significant impact of $41 \$$ per ha on the income. The additional income is more important for men (56\$) than women (11\$). These findings suggest that the use of seasonal forecast increases the productivity of rural communities and affects men and women differently. The access to and use of SF should therefore be widely promoted among farmers' organizations; women's associations should be particularly targeted.
\end{abstract}

Keywords: seasonal forecast; impact; yield; income; LATE

\section{Introduction}

Climate change affects men and women differently depending on their level of vulnerability, their country of residence and the nature of their livelihoods [1-4]. Climate is the primary determinant of agricultural productivity in sub-Saharan Africa (SSA) [5]. It affects the food systems in several ways, ranging from direct effects on crop production to changes in market, food prices and supply chain infrastructure [6].

In SSA, several studies, e.g., [7-10], have demonstrated the negative impacts of climate change in agriculture. Jalloh et al. [10] showed that, in Senegal, climate change will lead to an overall yield loss of between 5 and 25 percent for groundnuts. Roudier et al. [7] found that the temperature increases have been found to reduce the yields and quality of many crops, most importantly cereal and feed grains. According to Food and Agriculture Organization (FAO) [11], in SSA, the cultivated area for 
major crops has doubled since 1960 and the yield per unit of land has been stagnant for these crops. Blanc [9] disclosed that, in 2100 in SSA, in a case without climate change, yield changes will be near zero for cassava and will range from $-19 \%$ to $+6 \%$ for maize, from $-38 \%$ to $-13 \%$ for millet and from $-47 \%$ to $-7 \%$ for sorghum under alternative climate change scenarios. In this context, the use of weather and climate information services (WCIS) has become an essential tool for adaptation to climate change. Substantial benefits of WCIS in agroecosystems are reported for several countries in Africa [4]. In Senegal, WCIS has become an agricultural input for crop production for farmers and fisherfolk who use it to improve their resilience under climate change [12]. In Mali, Niger and Burkina Faso, seasonal forecast information reportedly helped millet and sorghum farmers to make mixed strategic decisions such as when to apply manure or chemical fertilizers and when to sow crops [13]. More specifically, a farmer could sow his corn in June after heavy rain depending on the nature of the seasonal forecast. Additionally, if a dry spell is planned for 10 days, the farmer can delay sowing in order to avoid losses. These agricultural decisions informed by the seasonal forecast lead to strategic choices related to crop variety, site production, etc., and a better allocation of productive resources (labor, land, agricultural inputs). This will contribute to the improvement of farm productivity through a reduction in cost and crop losses and an increase or stabilization of yields and farm income [13,14]. Among the services offered through weather forecast, the seasonal forecast (SF) has been largely identified as one of the most effective adaptation strategies [13,15-22]. Seasonal weather forecasts are forecasts of average seasonal conditions over a region that are made at the edge of the onset of the rainy season. A seasonal forecast uses climate models to predict what the seasonal rainfall might look like. This information is valuable to farmers for decision-making in agriculture. Seasonal rainfall forecasts for the region of West Africa are routinely produced within the framework of the West African Regional Climate Outlook Forums (WARCOF), formerly known as PRESAO (Prévisions Saisonnières en Afrique de l'Ouest) [10]. In Senegal, the seasonal forecast is disseminated through seminars, bulletins and radio broadcast [20] and includes information related to the total rain, the rainfall frequency, rainfall distribution, the onset length and the temperature [23]. Various studies have highlighted the impacts of SF on agricultural productivity in SSA. Lo and Dieng [19] showed that the use of SF in Senegal increased agricultural yields and this led to the improvement of family welfare. In addition, Rao et al. [24] demonstrated that farmers with SF achieve higher yields, with attractive returns on investment. Similar results have been found in South Africa $[16,25,26]$. However, no study has looked at the gendered perspective on the impact of SF. Indeed, men and women are differently affected by climate change due to inequalities between them. Women and men perceive some weather impacts on crops differently and diverge in how they receive, share, understand and act upon weather-related information [2]. In Africa, 80\% of the agricultural production comes from small farmers who are mostly rural women (almost $50 \%$ in SSA) [27]. Women represent the largest percentage of the workforce in the agricultural sector but do not have access to or control over all land and productive resources. They make up almost $50 \%$ of the agricultural labor force in sub-Saharan Africa, an increase from around 45\% in 1980, and their labor share could well exceed 60\% in many African countries [28]. In Senegal, women typically have less access to land, to labor and to credit, the result of historical social and legal barriers that have limited their access, their educational opportunities and their economic advancement in rural areas [27]. Moreover, in many ways, climate change could expose and exacerbate these pre-existing gender inequalities, making poor women in particular more vulnerable to its effects and preventing them from participating equally in its solutions [29].

This study is an attempt to (i) determine the gendered access to and use of seasonal forecast and (ii) identify the gender differential impact of the use of seasonal forecast on the main crop yields and farmer income.

The following sections are presented below: Section 2 outlines the theoretical framework as well as the empirical model, study site and the sampling; the results are presented in Section 3, followed by the discussion in Section 4 and finally the conclusions are developed in Section 5. 


\section{Materials and Methods}

\subsection{Theorical Framework for Impact Assesment}

In order to determine the impact of the use of seasonal forecast, a non-experimental approach was used. This approach is based on the framework of potential incomes proposed by Rubin [30]. Under this framework, the use of SF is considered as the "treatment", the additional income or yield is "the result" of the treatment. Indeed, each individual has two potential outcomes (with the treatment $y^{1}$ or without treatment $y^{0}$ ) and the impact of the use of SF on the income (or a yield) for a farmer who was randomly selected from the population of those who used the SF is given by the average treatment effect (ATE).

$$
\Delta_{\mathrm{ATE}}=E(\Delta)=E\left(y^{1}\right)-E\left(y^{0}\right)
$$

The method of potential incomes is based on the stable unit treatment values assumption (SUTVA), which assumes that the potential outcomes for any unit do not vary with the treatments assigned to other units. In addition, this assumption excludes general equilibrium effects and cross effects [31,32]. However, due to the nature of the data collected (observational data), there may be selection biases. These biases can be observable biases (the differences in the observed result can occur due to observable characteristics), unobservable biases (the differences are due to unobservable characteristics such as motivation) or endogenous biases (treated individuals may not comply with the treatment as assigned) [33,34]. Thus, the existence of these biases can lead to an overestimation or underestimation of the observed result $[33,35,36]$. Specifically, a difference in an individual's potential outcomes may not be due to the treatment but merely to unobserved factors. As a result, the average treatment effect for the whole population is different from the average treatment effect that could be obtained if the treatment was randomly assigned and if each individual in the population complied with treatment $[33,35]$. In this case, a causal interpretation is given only if each individual follows the assigned treatment. To deal with these biases, Imbens and Angrist [35] suggested the local average treatment effect (LATE) which gives the treatment effect of the sub-population of compliers (those who are effectively using the SF). Indeed, the use of SF is an endogenous choice that leads to the existence of endogenous bias. We have therefore used the LATE parameter to determine the causal effect of the use of SF in this study. The estimation of such a parameter requires the existence of an instrumental variable $z$ that influences directly the use of SF but has no direct influence on the outcomes (yield and agricultural income in this study). We have then chosen the access to and knowledge of the SF as an instrument because an individual cannot use SF without having access to it and the access does not directly lead to its use. Moreover, an individual may have access to the SF, but if he did not know about it, he may not use it effectively. In addition, the access to and the knowledge of the SF does not directly affect the yield or the income. Furthermore, the use of this parameter requires an assumption that defines the absence of non-compliers in the population.

With regard to estimators, we used the "local average response function" (LARF) from Abadie [34] to estimate the LATE parameter because the diffusion of SF was not randomly distributed. In this case, the instrument is not totally independent of the potential outcomes $y^{1}$ and $y^{0}$ but will become so, conditionally to the independent variables $x$ that determine the result $y[30,37]$. We used the regression function ordinary least square (OLS), which considers that the impact of the use of SF is constant for the whole population. Moreover, for the consistency of the OLS estimation, we assume that there is a linear relationship between the income/yield, the use of seasonal forecast and the covariates. Under this assumption and for any function $g(y, A, x)$, an impact estimator for the sub-population of potential users (LATE) is given by the following equation $[34,38]$ :

$$
E\left[g(y, A, x) \mid A_{1}=1\right]=\frac{1}{P\left(A_{1}=1\right)} E[k \cdot g(y, A, x)]
$$


where $k=1-\frac{z}{P(z=1 \mid x)}(1-A)$ represents the weight which takes the value 1 for potential users of SF and negative values otherwise. The conditional probability $P(z=1 \mid x)$ has been estimated using the probit model. This last Equation (2) is named the "local average response function (LARF)" and can be estimated using the following specification [34]:

$$
E\left(y \mid x, A_{i}=1\right)=\propto_{0}+\propto_{1} A+\beta X+\gamma A X \mathrm{~d}
$$

where $\alpha, \beta, \gamma$ are the vectors of covariates and

$$
L A T E=\propto_{1}+\gamma X
$$

The aim of this study is to calculate the impact of the use of SF on the agricultural net income per hectare and on the yield of the five main crops in the area of the study. The net income is the result of the value of the production deduced from operating expenses. The users of SF are those who took at least one decision after receiving SF. The non-users or non-adopters are those who did not take any decision based on SF or any other climate information (cumulative rain forecast, temperature, onset of the season, etc.). The chi-squared $\left(\chi^{2}\right)$ test (for qualitative data) and the test of Student (for numeric data) were used for mean comparison and the significance of variables, respectively.

\subsection{Empirical Model}

The literature review showed that several variables affect the use and the impact of SF on crop productivity $[16,19,25,39-41]$. Socioeconomic characteristics such as age, marital status, level of education and household size influence the access to and use of weather forecast. Moreover, the access to SF is facilitated by farmers' organizations and their relations with project or extension services $[2,42,43]$. The usual dissemination channels are radios or mobile phones through SMS, voice messaging and mobile applications (web, Facebook, WhatsApp, etc.). People who possess these platforms have a higher probability of obtaining information [12]. Being a client of a microfinance institution may increase the capacity of farmers to make appropriate decisions related to crop management. These variables have also been found in similar studies determining the impact of the use of innovation technologies in Africa [44-47]. The following table (Table 1) lists the variables used.

\begin{tabular}{|c|c|}
\hline Variables & Description \\
\hline Age & Age of the farmer \\
\hline Marital status & Dummy $=1$ if the farmer is married \\
\hline Formal education & Dummy $=1$ if the farmer has been in formal school \\
\hline Experience as member of an association & No. of years of experience as member of association \\
\hline Member of farmers' organization & Dummy $=1$ if the farmer is member of farmer's organization \\
\hline No. of years of experience as a farmer & No. of years of experience as farmer \\
\hline $\begin{array}{c}\text { Relation with project/ Non-governmental } \\
\text { organization (NGO) }\end{array}$ & Dummy $=1$ if the farmer has a relation with project/NGO \\
\hline Relation with agriculture extension services & $\begin{array}{c}\text { Dummy }=1 \text { if the farmer has a relation with } \\
\text { technical services }\end{array}$ \\
\hline Microfinance & $\begin{array}{c}\text { Dummy }=1 \text { if the farmer has a relation with } \\
\text { microfinance institution }\end{array}$ \\
\hline Training in climate change & $\begin{array}{l}\text { Dummy }=1 \text { if the farmer has been trained on climate change } \\
\text { in } 2018\end{array}$ \\
\hline Mobile phone & Dummy $=1$ if the farmer owns mobile phone \\
\hline Radio & Dummy $=1$ if the farmer owns radio \\
\hline Television & Dummy $=1$ if the farmer owns television \\
\hline No. of crops & No. of crops practiced \\
\hline Household size & Household size \\
\hline Level of confidence & $\begin{array}{c}\text { Dummy }=1 \text { if the farmer is very confident about the } \\
\text { Met Services }\end{array}$ \\
\hline
\end{tabular}

Table 1. Description of the variables introduced in the model. 


\subsection{Study Site, Sampling and Data}

The study was carried out in 2019 in five regions in Senegal, namely Kaolack, Kaffrine, Kolda, Sedhiou and Ziguinchor (Figure 1), where almost $60 \%$ of the national cereal production is concentrated [48]. Agriculture and livestock constitute the mainstay of Senegal, representing approximately $17 \%$ of the gross domestic product (GDP) and employing $70 \%$ of the population [49]. Agricultural land in Senegal constitutes approximately $46 \%$ of the country's total land area [50]. Rainfall is the key determinant of the agricultural production as less than $5 \%$ of land cultivated is under irrigation. Moreover, the agricultural economy is characterized by the dominance of smallholder farmers cultivating millet, sorghum, maize and rice for subsistence purposes. The country's main cash crops include groundnut and cotton.

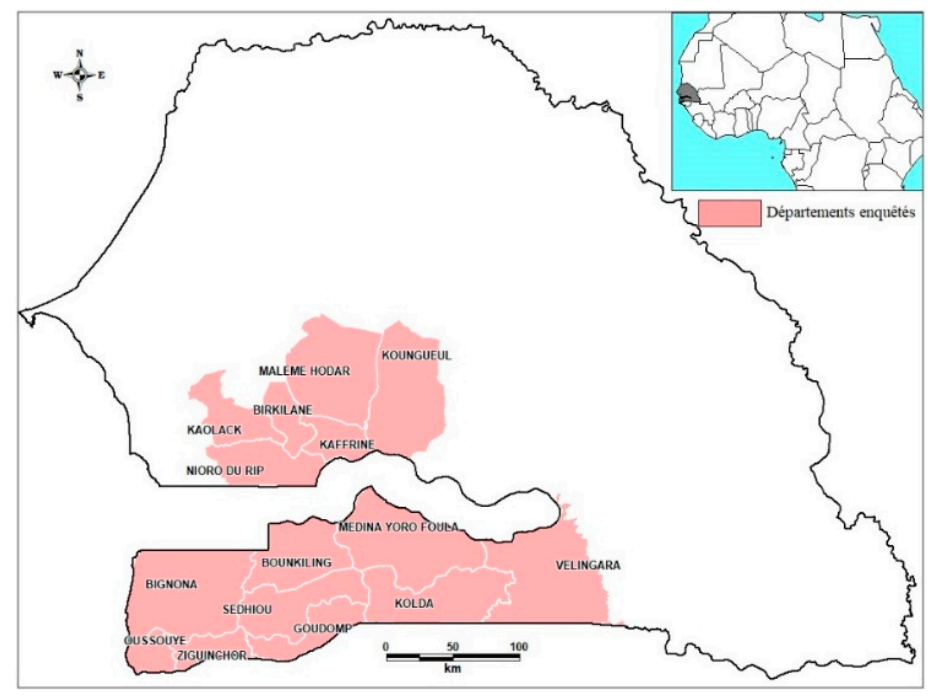

Figure 1. Site study.

Data were collected from a sample of 1500 farmers of whom $56 \%$ were men and $44 \%$ were women. We used a sampling frame of 12,484 member farmers of the farmers' organizations, locally called consolidation networks $(\mathrm{CN})$. The $\mathrm{CNs}$ are organizations of farmers grouped around profitable and competitive value chains (rice, millet, maize, peanut, etc.). These networks are similar to small enterprises, with qualified staff in charge of the production quality control and the capacity building of their members. They include also administrative staff who manage relations with financial institutions and private operators for marketing. The database includes $50 \mathrm{CN}$ with 9562 beneficiaries and 2922 non-beneficiaries. Beneficiaries are those who receive weather and climate services from the National Meteorological Service and through community radios and social networks. Non-beneficiaries are those who do not receive WCIS. Around 1500 farmers were randomly selected using a stratified two-stage sampling method where $\mathrm{CN}$ represents the primary unit and farmers represent the secondary unit. The sex and area of residence were considered as interest variables for the sampling. Table 2 below presents the sample distribution of the present study.

Table 2. Sample by region and sex.

\begin{tabular}{cccc}
\hline Region & Male & Female & Total \\
\hline KAFFRINE & 165 & 94 & 259 \\
KAOLACK & 111 & 3 & 114 \\
KOLDA & 370 & 238 & 608 \\
SEDHIOU & 70 & 212 & 282 \\
ZIGUINCHOR & 128 & 109 & 237 \\
\hline Total & 844 & 656 & 1500 \\
\hline
\end{tabular}


We interviewed selected farmers using a structured questionnaire to record information on socioeconomic characteristics, input use, farmers' access to and use of WCIS, farm income, etc. Stata software was used for descriptive and econometric analysis.

\section{Results}

\subsection{Descriptive Statistics}

\subsubsection{Socioeconomic Characteristics}

Table 3 presents the socioeconomic characteristics of respondents according to both sex and access to SF. Adopters of SF represented on average 10\%. Among men, $12 \%$ used the SF against $8 \%$ among women. Significant differences could be observed among men and women in socioeconomic characteristics. Around $64 \%$ of the respondents were heads of households. This proportion represented $89 \%$ and $34 \%$, respectively, among men and women. More than half of the respondents were over 40 years old. The average age was 48 for men and 44 for women (Table 4 ). The average size of households was 16 among men and 15 in women. Most of the respondents (98\%) were married. The dominant ethnicity was "Peulh", followed by "Wolof" and "Diola". Regarding the level of education, among women, almost $64 \%$ of non-users of SF had not been in school against $39 \%$ of users of SF. Among men, the majority learned Koran/Arabic and no significant difference was observed within them. The surveyed farmers had, for the most part, more than 20 years of experience in agriculture and differences were observed in adopters and non-adopters regardless of sex (Table 4).

Agriculture was the main activity of the respondent farmers. Regarding membership of an association, we note that almost all of the adopters (more than 98\%) were part of an association; significant differences were noted in the adopters and non-adopters. Few farmers (less than $1 \%$ ) had relations with the national agricultural research services. On average, $40.72 \%$ of men and more than $50 \%$ of women had relationships with development projects and/or NGOs.

Regarding climate services, the respondents were confident about the information from the National Met Service. Among men, 37\% of users of SF trusted information from the Met Service, against $48 \%$ in non-adopters. The opposite was observed for women, where $37 \%$ of adopters trusted the information, against $30 \%$ among non-adopters. Concerning the means of communication, a greater number of men had mobile phones (on average 95.6\%) compared to $76 \%$ among women. Around $43.86 \%$ of adopters against $8 \%$ of non-adopters had received training in climate change; $45 \%$ of men and $41 \%$ of women (both users of $\mathrm{SF}$ ) benefitted from training on climate change.

\subsubsection{Arable Land and Farm Size}

Table 5 depicts the available arable land and farm sizes of farmers. There was a significant difference between men and women in the sample. Men possessed at least 6 ha and women 2.8 ha. Female adopters of SF had on average 4.39 ha and those who did not use the SF possessed 2.7 ha of the area. Regarding the cultivated area, men used at least 6 ha, which was much more compared to women, who utilized 3.57 ha. Concerning the status of adoption, results show that users of SF had the largest amount of cultivated area than the others. The difference refers to users and non-users among men and among women. 
Table 3. Farmers' socioeconomic characteristics by gender and adoption status.

\begin{tabular}{|c|c|c|c|c|c|c|c|c|c|c|}
\hline \multicolumn{2}{|l|}{ Sex } & \multicolumn{3}{|c|}{ Male } & \multicolumn{3}{|c|}{ Female } & \multicolumn{3}{|c|}{ All } \\
\hline \multicolumn{2}{|l|}{ Users of Seasonal Forecast } & Yes & No & All & Yes & No & All & Yes & No & All \\
\hline \multirow{2}{*}{ Farmers } & $\mathrm{N}$ & 73 & 541 & 614 & 41 & 464 & 505 & 114 & 1014 & 1128 \\
\hline & $\%$ & 11.89 & 88.11 & 56.04 & 8.12 & 91.88 & 43.96 & 10.11 & 89.89 & 100 \\
\hline Head of household \#++ & Yes & 84.93 & 88.17 & 87.79 & 48.78 & 33.41 & 34.65 & 71.93 & 62.89 & 63.81 \\
\hline \multirow{5}{*}{ Age } & Under 30 years & 1.37 & 5.91 & 5.37 & 9.76 & 11.64 & 11.49 & 4.39 & 8.56 & 8.13 \\
\hline & Between 30 and 40 years & 19.18 & 21.07 & 20.85 & 14.63 & 26.08 & 25.15 & 17.54 & 23.38 & 22.79 \\
\hline & Between 40 and 50 years & 26.03 & 27.91 & 27.69 & 24.39 & 25.65 & 25.54 & 25.44 & 26.87 & 26.72 \\
\hline & Between 50 and 60 years & 39.73 & 28.28 & 29.64 & 36.59 & 28.23 & 28.91 & 38.6 & 28.26 & 29.31 \\
\hline & Over 60 years & 13.7 & 16.82 & 16.45 & 14.63 & 8.41 & 8.91 & 14.04 & 12.94 & 13.05 \\
\hline \multirow{5}{*}{ Ethnicity *\# } & Wolof & 27.4 & 21.81 & 22.48 & 12.2 & 9.91 & 10.1 & 21.93 & 16.32 & 16.89 \\
\hline & Peulh & 57.53 & 56.01 & 56.19 & 46.34 & 40.09 & 40.59 & 53.51 & 48.66 & 49.15 \\
\hline & Sérère & 1.37 & 0.92 & 0.98 & 4.88 & 1.08 & 1.39 & 2.63 & 1 & 1.16 \\
\hline & Diola & 6.85 & 13.12 & 12.38 & 19.51 & 16.16 & 16.44 & 11.4 & 14.53 & 14.21 \\
\hline & Mandingue & 0 & 3.88 & 3.42 & 7.32 & 23.28 & 21.98 & 2.63 & 12.84 & 11.8 \\
\hline Marital status \#\#+++ & Married & 97.26 & 97.6 & 97.56 & 58.54 & 84.48 & 82.38 & 83.33 & 91.54 & 90.71 \\
\hline \multirow{5}{*}{ Level of instruction \#\#++++ } & None & 21.92 & 29.76 & 28.83 & 39.02 & 63.79 & 61.78 & 28.07 & 45.47 & 43.7 \\
\hline & Arab/Coran & 46.58 & 43.81 & 44.14 & 17.07 & 16.38 & 16.44 & 35.96 & 31.14 & 31.64 \\
\hline & $\begin{array}{l}\text { Literate in a foreign } \\
\text { language }\end{array}$ & 6.85 & 5.18 & 5.37 & 17.07 & 5.39 & 6.34 & 10.53 & 5.27 & 5.81 \\
\hline & $\begin{array}{l}\text { Primary school } \\
\text { Page }\end{array}$ & 12.33 & 13.68 & 13.52 & 19.51 & 11.21 & 11.88 & 14.91 & 12.54 & 12.78 \\
\hline & Secondary middle school & 6.85 & 4.07 & 4.4 & 2.44 & 1.94 & 1.98 & 5.26 & 3.08 & 3.31 \\
\hline \multirow{4}{*}{ Number of years of agricultural experience $* \#+++$} & Less than 10 & 2.74 & 3.14 & 3.09 & 4.88 & 8.62 & 8.32 & 3.51 & 5.62 & 5.41 \\
\hline & Between 10 and 20 & 8.22 & 17.74 & 16.61 & 17.07 & 24.78 & 24.16 & 11.4 & 20.81 & 19.86 \\
\hline & Between 20 and 30 & 45.21 & 48.24 & 47.88 & 39.02 & 47.63 & 46.93 & 42.98 & 47.53 & 47.07 \\
\hline & More than 30 & 43.84 & 30.87 & 32.41 & 39.02 & 18.97 & 20.59 & 42.11 & 26.04 & 27.66 \\
\hline Principal activity *\#+++ & Farming/breeding & 94.52 & 98.15 & 97.72 & 90.24 & 98.28 & 97.62 & 92.98 & 98.21 & 97.68 \\
\hline Member of an association ${ }^{* *} \# \#++++$ & Yes & 97.26 & 77.08 & 79.48 & 100 & 87.72 & 88.71 & 98.25 & 81.99 & 83.65 \\
\hline $\begin{array}{l}\text { Relation with a project } \\
\end{array}$ & Yes & 34.25 & 41.59 & 40.72 & 48.78 & 50.65 & 50.5 & 39.47 & 45.77 & 45.13 \\
\hline $\begin{array}{l}\text { Relation with the National Agricultural Research } \\
\text { Institute } \#++\end{array}$ & Yes & 1.37 & 0.18 & 0.33 & 2.44 & 0 & 0.2 & 1.75 & 0.1 & 0.27 \\
\hline \multirow{4}{*}{ Level of confidence in the weather forecast ${ }^{* * *+++}$} & Very confident & 36.99 & 47.5 & 46.25 & 36.59 & 29.53 & 30.1 & 36.84 & 39.2 & 38.96 \\
\hline & Just confident & 34.25 & 33.46 & 33.55 & 34.15 & 40.3 & 39.8 & 34.21 & 36.62 & 36.37 \\
\hline & Little confident & 15.07 & 15.53 & 15.47 & 19.51 & 25.22 & 24.75 & 16.67 & 20 & 19.66 \\
\hline & Not at all confident & 13.7 & 3.51 & 4.72 & 9.76 & 4.96 & 5.35 & 12.28 & 4.18 & 5 \\
\hline Mobile phone possession & Yes & 95.89 & 95.56 & 95.6 & 82.93 & 75.22 & 75.84 & 91.23 & 86.17 & 86.68 \\
\hline A member of the house watches TV \#\#+++ & Yes & 53.42 & 48.61 & 49.19 & 73.17 & 50.86 & 52.67 & 60.53 & 49.65 & 50.76 \\
\hline A member of the house listens to the radio \#\#+++ & Yes & 95.89 & 92.05 & 92.51 & 97.56 & 83.41 & 84.55 & 96.49 & 88.06 & 88.92 \\
\hline Training in climate change ${ }^{* * * \# \#++++}$ & Yes & 45.21 & 8.87 & 13.19 & 41.46 & 6.9 & 9.7 & 43.86 & 7.96 & 11.62 \\
\hline
\end{tabular}

* Significance among men: *** $=$ significant at $1 \%,{ }^{*}=$ significant at $10 \%$; \# significance among women: (\#\#\# 1\% \#\# 5\%, \# 10\%); + significance in the whole sample (+++ $\left.1 \%++5 \%\right)$. 
Table 4. Age, size of household and farmer experience in farming.

\begin{tabular}{|c|c|c|c|c|c|}
\hline & Sex & Modality & $\mathbf{N}$ & Mean & Standard Deviation \\
\hline \multirow{8}{*}{ Age } & \multirow{4}{*}{ Male } & Yes & 73 & 49.44 & 10.99 \\
\hline & & No & 541 & 47.84 & 12.55 \\
\hline & & All & 614 & 48.03 & 12.38 \\
\hline & & Difference & & 1.60 & \\
\hline & \multirow{4}{*}{ Female } & Yes & 41 & 48.05 & 12.87 \\
\hline & & No & 464 & 43.85 & 12.57 \\
\hline & & All & 505 & 44.19 & 12.63 \\
\hline & & Difference & & $4.201798^{* *}$ & \\
\hline \multirow{8}{*}{ Size of household } & \multirow{4}{*}{ Male } & Yes & 73 & 17.01 & 9.05 \\
\hline & & No & 541 & 16.13 & 9.38 \\
\hline & & All & 614 & 16.24 & 9.34 \\
\hline & & Difference & & 0.88 & \\
\hline & \multirow{4}{*}{ Female } & Yes & 41 & 14.66 & 7.85 \\
\hline & & No & 464 & 15.41 & 8.03 \\
\hline & & All & 505 & 15.35 & 8.01 \\
\hline & & Difference & & -0.76 & \\
\hline \multirow{8}{*}{ Years of experience } & \multirow{4}{*}{ Male } & Yes & 73 & 29.99 & 10.72 \\
\hline & & No & 541 & 27.72 & 11.83 \\
\hline & & All & 614 & 27.99 & 11.72 \\
\hline & & Difference & & $2.269111 *$ & \\
\hline & \multirow{4}{*}{ Female } & Yes & 41 & 27.61 & 12.62 \\
\hline & & No & 464 & 22.99 & 11.17 \\
\hline & & All & 505 & 23.36 & 11.35 \\
\hline & & Difference & & $4.620532 * * *$ & \\
\hline
\end{tabular}

$* * *=$ significant at $1 \%,{ }^{* *}=$ significant at $5 \%,{ }^{*}=$ significant at $10 \%$.

Table 5. Available and cultivated area by sex and status of adoption.

\begin{tabular}{|c|c|c|c|c|c|}
\hline & Sex & Use of SF & $\mathbf{N}$ & Mean & Standard Deviation \\
\hline \multirow{8}{*}{ Available area } & \multirow{4}{*}{ Male } & Yes & 73 & 7.186986 & 12.23176 \\
\hline & & No & 541 & 6.100129 & 6.721459 \\
\hline & & All & 614 & 6.229349 & 7.582548 \\
\hline & & Difference & & 1.086857 & \\
\hline & \multirow{4}{*}{ Female } & Yes & 41 & 4.386585 & 6.537048 \\
\hline & & No & 464 & 2.711207 & 3.738648 \\
\hline & & All & 505 & 2.847228 & 4.054841 \\
\hline & & Difference & & $1.675378^{* * *}$ & \\
\hline \multirow{8}{*}{ Cultivated area } & \multirow{4}{*}{ Male } & Yes & 73 & 6.440411 & 12.24563 \\
\hline & & No & 541 & 5.055823 & 5.472056 \\
\hline & & All & 614 & 5.22044 & 6.647686 \\
\hline & & Difference & & $1.384588 * *$ & \\
\hline & \multirow{4}{*}{ Female } & Yes & 41 & 3.565854 & 4.808761 \\
\hline & & No & 464 & 2.047274 & 2.284699 \\
\hline & & All & 505 & 2.170564 & 2.608225 \\
\hline & & Difference & & $1.51858^{* * *}$ & \\
\hline
\end{tabular}

${ }^{* * *}=$ significant at $1 \%,{ }^{* *}=$ significant at $5 \%$. 


\subsubsection{Yield and Income Comparison}

The mean comparison of the yield and income was conducted according to gender and the use of SF:

- Yield comparison

Regarding the yield (Table 6), the average yield of millet by farmers was around $740 \mathrm{~kg} / \mathrm{ha}$. There was at least a difference of $200 \mathrm{~kg} / \mathrm{ha}$ between users and non-users of seasonal forecast in the men's group. There was almost no difference between men and women in millet yield. Women who grew sorghum did not use SF in the sample. However, Table 5 depicts a high yield for women $(951 \mathrm{~kg} / \mathrm{ha})$ compared to men $(698 \mathrm{~kg} / \mathrm{ha})$. There was a significant difference between users of SF and non-users in the men's group (1467 kg/ha against $647 \mathrm{~kg} / \mathrm{ha})$. Furthermore, no difference was observed between men and women regarding maize yield. The mean was $880 \mathrm{~kg} / \mathrm{ha}$ and the maize yield was the highest for men $(902.7 \mathrm{~kg} / \mathrm{ha})$ than women $(785 \mathrm{~kg} / \mathrm{ha})$. With regard to rice crop, there was a difference between users and non-users among men and women. The yield of men $(966 \mathrm{~kg} / \mathrm{ha})$ was higher as compared to the yield for women $(663 \mathrm{~kg} / \mathrm{ha})$. The mean yield of rice was $761 \mathrm{~kg} / \mathrm{ha}$. Regarding the groundnut, the mean yield was $991 \mathrm{~kg} / \mathrm{ha}$. The yield from men was higher $(1032 \mathrm{~kg} / \mathrm{ha})$ compared to the one for women $(884 \mathrm{~kg} / \mathrm{ha})$. A significant difference was noted between users and non-users among women: $645 \mathrm{~kg} / \mathrm{ha}$ for users of SF and $913.6 \mathrm{~kg} / \mathrm{ha}$ for non-users.

Table 6. Yield comparison by gender and adoption.

\begin{tabular}{|c|c|c|c|c|c|}
\hline Crops & Gender & Users of Seasonal Forecast & $\mathbf{N}$ & Mean (kg/ha) & Standard Deviation \\
\hline \multirow{9}{*}{ Millet } & \multirow{3}{*}{ Male } & Yes & 46 & 924.2 & 504.7 \\
\hline & & No & 372 & 721.4 & 494.7 \\
\hline & & All & 418 & 743.7 & 499.2 \\
\hline & \multirow{3}{*}{ Female } & Yes & 13 & 726.9 & 378.4 \\
\hline & & No & 105 & 725.4 & 453.1 \\
\hline & & All & 118 & 725.5 & 444.1 \\
\hline & \multirow{3}{*}{ All } & Yes & 59 & 880.8 & 483.8 \\
\hline & & No & 477 & 722.3 & 485.4 \\
\hline & & All & 536 & 739.7 & 487.3 \\
\hline \multirow{9}{*}{ Sorghum } & \multirow{3}{*}{ Male } & Yes & 3 & 1467.3 & 1794.6 \\
\hline & & No & 45 & 647.0 & 536.6 \\
\hline & & All & 48 & 698.3 & 668.5 \\
\hline & \multirow{3}{*}{ Female } & Yes & 0 & & \\
\hline & & No & 10 & 951.2 & 302.7 \\
\hline & & All & 10 & 951.2 & 302.7 \\
\hline & \multirow{3}{*}{ All } & Yes & 3 & 1467.3 & 1794.6 \\
\hline & & No & 55 & 702.4 & 513.8 \\
\hline & & All & 58 & 741.9 & 626.3 \\
\hline \multirow{9}{*}{ Maize } & \multirow{3}{*}{ Male } & Yes & 36 & 910.2 & 994.7 \\
\hline & & No & 272 & 901.8 & 769.2 \\
\hline & & All & 308 & 902.7 & 796.9 \\
\hline & \multirow{3}{*}{ Female } & Yes & 7 & 757.1 & 806.4 \\
\hline & & No & 64 & 788.2 & 869.2 \\
\hline & & All & 71 & 785.1 & 857.8 \\
\hline & \multirow{3}{*}{ All } & Yes & 43 & 885.3 & 959.5 \\
\hline & & No & 336 & 880.1 & 789.1 \\
\hline & & All & 379 & 880.7 & 808.8 \\
\hline
\end{tabular}


Table 6. Cont.

\begin{tabular}{|c|c|c|c|c|c|}
\hline \multirow{9}{*}{ Rice } & \multirow{3}{*}{ Male } & Yes & 26 & 1151.4 & 1001.6 \\
\hline & & No & 160 & 936.1 & 898.0 \\
\hline & & All & 186 & 966.2 & 913.3 \\
\hline & \multirow{3}{*}{ Female } & Yes & 33 & 783.2 & 723.3 \\
\hline & & No & 358 & 652.1 & 515.4 \\
\hline & & All & 391 & 663.2 & 536.1 \\
\hline & \multirow{3}{*}{ All } & Yes & 59 & 945.4 & 868.9 \\
\hline & & No & 518 & 739.8 & 669.8 \\
\hline & & All & 577 & 760.9 & 694.7 \\
\hline \multirow{9}{*}{ Groundnut } & \multirow{3}{*}{ Male } & Yes & 58 & 1118.5 & 620.9 \\
\hline & & No & 436 & 1020.6 & 771.5 \\
\hline & & All & 494 & 1032.1 & 755.5 \\
\hline & \multirow{3}{*}{ Female } & Yes & 21 & 645.1 & 358.3 \\
\hline & & No & 169 & 913.6 & 646.7 \\
\hline & & All & 190 & 884.0 & 626.5 \\
\hline & \multirow{3}{*}{ All } & Yes & 79 & 992.6 & 599.1 \\
\hline & & No & 605 & 990.7 & 739.8 \\
\hline & & All & 684 & 990.9 & 724.6 \\
\hline
\end{tabular}

- Income comparison

Table 7 shows the agricultural income of respondents by gender and level of adoption. Among men, the results describe a significant difference $(27,598 \mathrm{XOF} / 48 \$(1 \mathrm{USD}=579 \mathrm{XOF}))$ between users and non-users. Among women, the difference was not significant. The mean income of farmers was $137,941 \mathrm{XOF}$ or $238 \$$. In addition, the mean income was $131,364 \mathrm{XOF}$ or $227 \$$ for women, against $143,342 \mathrm{XOF}$ or $248 \$$ for men, and the difference was not statistically different.

Table 7. Income comparison by gender and adoption.

\begin{tabular}{|c|c|c|c|c|}
\hline Sex & $\mathbf{M}$ & $\mathbf{N}$ & Mean (XOF) & Standard Deviation \\
\hline \multirow{4}{*}{ Male } & Non-users & 541 & $140,070.8$ & $125,939.4$ \\
\hline & Users & 73 & $167,669.1$ & $122,849.3$ \\
\hline & All & 614 & 143,352 & $125,795.4$ \\
\hline & Difference & & $-27,598.3^{* *}$ & \\
\hline \multirow{4}{*}{ Female } & Non-users & 464 & 130,605 & $120,289.9$ \\
\hline & Users & 41 & $139,953.9$ & 182,833 \\
\hline & All & 505 & 131,364 & $126,301.7$ \\
\hline & Difference & & -9348.92 & \\
\hline \multirow{4}{*}{ Total } & Non-users & 114 & $157,701.4$ & $147,062.8$ \\
\hline & Users & 1005 & $135,700.5$ & $123,392.6$ \\
\hline & All & 1119 & $137,941.9$ & 126,109 \\
\hline & Difference & & $22,000.85$ & $12,451.28$ \\
\hline
\end{tabular}

\subsubsection{Access and Use of SF}

Table 8 presents the access to and use of SF according to gender and the adoption status. Around $28 \%$ of respondents had access to SF, from which $56.93 \%$ were male and $43 \%$ female. Moreover, $10 \%$ of individuals used SF effectively; among these, $64 \%$ were men and $36 \%$ women. 
Table 8. Access to and use of seasonal forecast by gender and adoption.

\begin{tabular}{lccccccc}
\hline \multirow{2}{*}{ Gender Statistic } & \multicolumn{3}{c}{ Access to SF } & \multicolumn{3}{c}{ Users of SF ** } \\
\cline { 2 - 8 } & & Yes & No & All & Yes & No & All \\
\hline \multirow{2}{*}{ Male } & $\mathrm{N}$ & 234 & 596 & 830 & 73 & 541 & 614 \\
& $\%$ & 56.93 & 55.7 & 56.04 & 64.04 & 53.83 & 54.87 \\
\hline \multirow{2}{*}{ Female } & $\mathrm{N}$ & 177 & 474 & 651 & 41 & 464 & 505 \\
& $\%$ & 43.07 & 44.3 & 43.96 & 35.96 & 46.17 & 45.13 \\
\hline \multirow{2}{*}{ All } & $\mathrm{N}$ & 411 & 1070 & 1481 & 114 & 1005 & 1119 \\
& $\%$ & 27.75 & 72.25 & 100 & 10.19 & 89.81 & 100 \\
\hline \multicolumn{3}{c}{$* *$ significant at 5\% (Student's test). }
\end{tabular}

Figure 2 shows the types of decision taken by men and women after the reception of seasonal forecast. The most common decisions were "the use of an early maturing crop variety", followed by "the modification of the sowing period" for both sexes. Few farmers chose to change the date of the preparation of the plot (labor, plough).

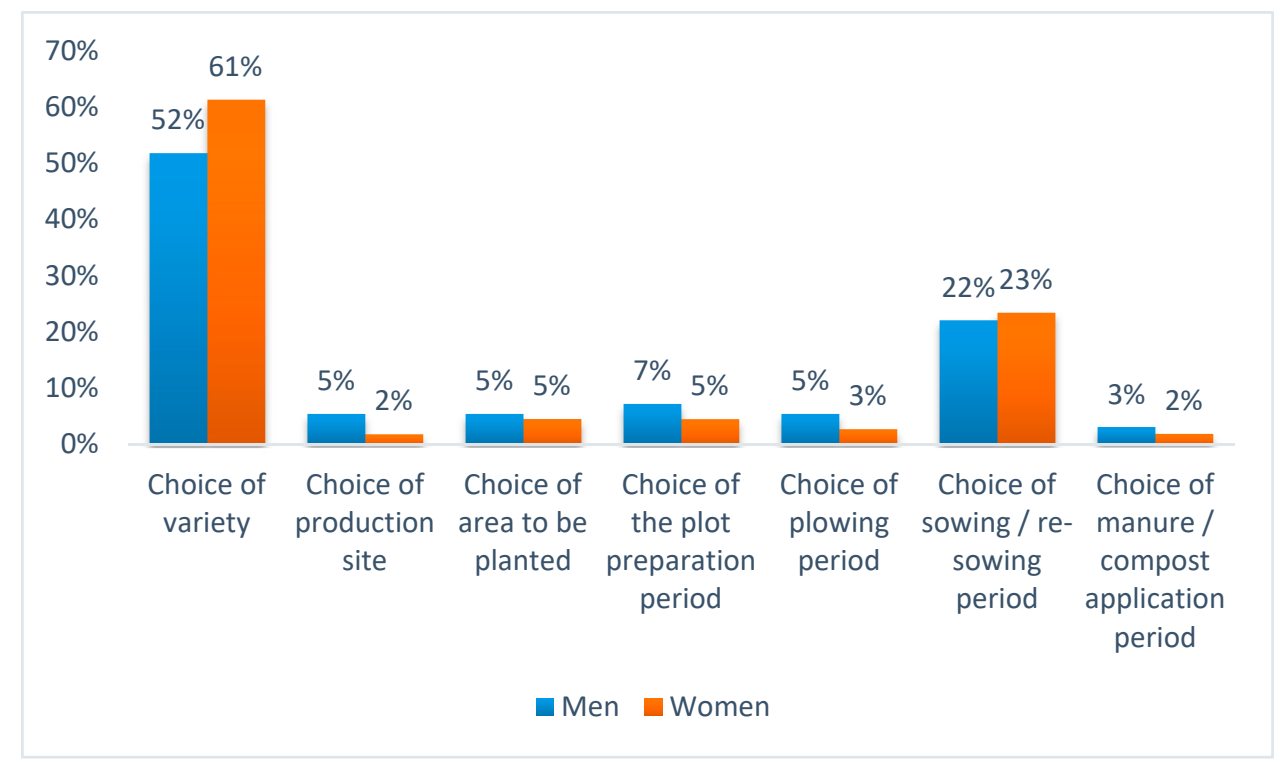

Figure 2. Decisions taken after the reception of seasonal forecast.

\subsection{Impact of the Use of SF on Main Crop Yields}

The results of the impact of the use of SF on main crops are presented in Table 9. The results show an additional yield of $158 \mathrm{~kg} / \mathrm{ha}$ for millet, $878 \mathrm{~kg} / \mathrm{ha}$ for sorghum and $139.78 \mathrm{~kg} / \mathrm{ha}$ for rice. There was a significant effect of the use SF on yield $(202.70 \mathrm{~kg} / \mathrm{ha})$ for millet yield among men. This impact was low $(16.67 \mathrm{~kg} / \mathrm{ha})$ for women. For sorghum, given that there were non-users in the women's group, the effect was calculated for men only and was $+886.53 \mathrm{Kg} / \mathrm{ha}$. However, a negative effect was observed among men in maize yield $(-105 \mathrm{~kg} / \mathrm{ha}$ ) and an additional gain of $+210 \mathrm{~kg} / \mathrm{ha}$ for women. For rice cropping, the impact of SF use was positive (+321 kg/ha) for men and negative for women $(-25 \mathrm{~kg} / \mathrm{ha})$. Regarding groundnut, a significant and negative effect was observed for women $(-278 \mathrm{~kg} / \mathrm{ha})$ and a positive effect for men $(+85.57 \mathrm{~kg} / \mathrm{ha})$. 
Table 9. Impact of the use of SF on the main crops.

\begin{tabular}{|c|c|c|c|c|}
\hline \multirow{2}{*}{ Crop } & \multirow{2}{*}{ Statistics } & \multicolumn{2}{|c|}{ Sex } & \multirow{2}{*}{ Total } \\
\hline & & Male & Female & \\
\hline \multirow{10}{*}{ Millet } & late & $202.7003^{* * *}$ & $16.6704^{* * *}$ & $158.0922^{* * *}$ \\
\hline & late & $(0.000000213)$ & (0.000000636) & (0.000000198) \\
\hline & diffmo & $202.8108^{* * *}$ & 1.560541 & $158.4683^{* *}$ \\
\hline & & $924.2391^{* * *}$ & $726.9231^{* * *}$ & $880.7627^{* * *}$ \\
\hline & mo_N1 & $(73.78025)$ & $(101.7092)$ & $(62.56851)$ \\
\hline & mo N0 & $721.4284^{* * *}$ & $725.3625^{* * *}$ & $722.2944^{* * *}$ \\
\hline & & $(25.67361)$ & $(44.38536)$ & (22.24103) \\
\hline & $\mathrm{N}$ & 418 & 118 & 536 \\
\hline & N1 & 46 & 13 & 59 \\
\hline & Nz1 & 410 & 115 & 525 \\
\hline \multirow{11}{*}{ Sorghum } & & $886.527^{* * *}$ & & $878.3913^{* * *}$ \\
\hline & late & $(0.0096732)$ & & $(0.0058903)$ \\
\hline & & 820.2892 & & 764.9812 \\
\hline & diffmo & $(867.949)$ & & (863.7879) \\
\hline & $\mathrm{moN}$ & $1467.333^{*}$ & & $1467.333^{*}$ \\
\hline & mo_No & (864.1794) & & (860.9585) \\
\hline & & $647.0441 * * *$ & & $702.3521 * * *$ \\
\hline & mo_N0 & $(80.80415)$ & & $(69.85694)$ \\
\hline & $\mathrm{N}$ & 48 & & 58 \\
\hline & N1 & 3 & & 3 \\
\hline & Nz1 & 36 & & 42 \\
\hline \multirow{11}{*}{ Maize } & & $-105.0478^{* * *}$ & $210.108^{* * * *}$ & $-54.71325 * * *$ \\
\hline & late & $(0.000000604)$ & $(0.005296)$ & $(0.000000869)$ \\
\hline & diff & 8.430372 & -31.02121 & 5.152838 \\
\hline & diffmo & $(170.5127)$ & $(306.4321)$ & (151.2637) \\
\hline & $\mathrm{moN} 1$ & $910.1852 * * *$ & $757.1429 * * *$ & $885.2713^{* * *}$ \\
\hline & mo_NI & $(163.9917)$ & $(286.2584)$ & (144.9938) \\
\hline & & $901.7548^{* * *}$ & $788.1641^{* * *}$ & $880.1185^{* * *}$ \\
\hline & mo_N0 & $(46.70464)$ & (109.347) & $(43.09885)$ \\
\hline & $\mathrm{N}$ & 308 & 71 & 379 \\
\hline & N1 & 36 & 7 & 43 \\
\hline & Nz1 & 353 & 80 & 433 \\
\hline \multirow{11}{*}{ Rice } & & $321.3293^{* * *}$ & $-25.31179 * * *$ & $139.779 * * *$ \\
\hline & late & $(0.000000204)$ & $(0.000000408)$ & $(0.000000299)$ \\
\hline & diff & 215.319 & 131.0487 & $205.6047 *$ \\
\hline & diftmo & (206.322) & (127.2601) & (116.1548) \\
\hline & $\mathrm{moN} 1$ & $1151.372 * * *$ & $783.1818^{* * *}$ & $945.4349^{* * *}$ \\
\hline & mo_No & (193.6653) & $(124.3038)$ & (112.3588) \\
\hline & & $936.0526^{* * *}$ & $652.1331^{* * *}$ & $739.8302 * * *$ \\
\hline & mo_N0 & (71.15149) & $(27.2708)$ & $(29.45237)$ \\
\hline & $\mathrm{N}$ & 186 & 391 & 577 \\
\hline & N1 & 26 & 33 & 59 \\
\hline & Nz1 & 205 & 282 & 487 \\
\hline \multirow{11}{*}{ Groundnut } & & $85.57264^{* * *}$ & $-278.0796^{* * *}$ & $-36.6594 * * *$ \\
\hline & late & $(0.0239357)$ & $(0.000000741)$ & $(0.000000537)$ \\
\hline & & 97.904 & $-268.5566 * * *$ & 1.935476 \\
\hline & diffmo & (89.02992) & (91.49708) & $(73.51857)$ \\
\hline & $\mathrm{mo} \mathrm{N1}$ & $1118.466^{* * *}$ & $645.0907^{* * *}$ & $992.6317^{* * *}$ \\
\hline & 110_NDI & (80.98535) & $(76.71514)$ & $(67.07537)$ \\
\hline & mo N0 & $1020.562^{* * *}$ & $913.6473^{* * *}$ & $990.6962^{* * *}$ \\
\hline & mo_No & (36.98241) & $(49.86485)$ & (30.09774) \\
\hline & $\mathrm{N}$ & 494 & 190 & 684 \\
\hline & N1 & 58 & 21 & 79 \\
\hline & Nz1 & 498 & 169 & 667 \\
\hline
\end{tabular}

\subsubsection{Impact of the Use of SF on Agricultural Income}

Table 10 presents the results of the impact of the use of SF on the agricultural income. Results show that the users of SF had an additional income of 23,958 XOF per ha (41 $\$ /$ ha). This impact was greater among men $32,397 \mathrm{XOF} / \mathrm{ha}(56 \$)$ than women $(6181 \mathrm{XOF} / \mathrm{ha}$ or $11 \$)$. 
Table 10. Impact of the use of SF on agricultural income.

\begin{tabular}{|c|c|c|c|}
\hline \multirow{2}{*}{ Parameter } & \multicolumn{2}{|c|}{ Sex } & \multirow{2}{*}{ Total } \\
\hline & Male & Female & \\
\hline late & $\begin{array}{c}32,397.39^{* * *} \\
(0.0000325)\end{array}$ & $\begin{array}{l}6181.402^{* * *} \\
(0.0001088)\end{array}$ & $\begin{array}{c}23,958.69 * * * \\
(0.0000422)\end{array}$ \\
\hline diffmo & $\begin{array}{c}27,598.3 * \\
(15,294.84)\end{array}$ & $\begin{array}{c}9,348.923 \\
(28,806.81)\end{array}$ & $\begin{array}{c}22,000.85 \\
(14,267.06)\end{array}$ \\
\hline mo_N1 & $\begin{array}{c}167,669.1^{* * *} \\
(14,302.91)\end{array}$ & $\begin{array}{c}139,953.9^{* * *} \\
(28,259.36)\end{array}$ & $\begin{array}{c}157,701.4^{* * *} \\
(13,725.42)\end{array}$ \\
\hline mo_N0 & $\begin{array}{c}140,070.8^{* * *} \\
(5418.383)\end{array}$ & $\begin{array}{l}130,605^{* * *} \\
(5589.377)\end{array}$ & $\begin{array}{c}135,700.5^{* * *} \\
(3893.842)\end{array}$ \\
\hline $\mathrm{N}$ & 614 & 505 & 1119 \\
\hline N1 & 73 & 41 & 114 \\
\hline Nz1 & 625 & 404 & 1029 \\
\hline
\end{tabular}

\subsubsection{Determinants of the Use of Seasonal Forecast}

We ran regressions for men, women and the entire population. Results (Table 11) show that the possession of a radio, the marital status, the cultivated area, the relation with extension services and formal education had significant and positive effects on the use of seasonal forecast among women. Membership of a farmers' organization and the relation with extension services had significant and positive effects on the use of seasonal forecast among men.

Table 11. Determinants of the use of SF.

\begin{tabular}{|c|c|c|c|}
\hline & Male & Female & Total \\
\hline Age & $\begin{array}{c}0.0034566 \\
(0.0082109)\end{array}$ & $\begin{array}{c}0.000378 \\
(0.0110395)\end{array}$ & $\begin{array}{c}0.0014755 \\
(0.0064131)\end{array}$ \\
\hline Marital status & $\begin{array}{c}0.1812215 \\
(0.3216277)\end{array}$ & $\begin{array}{c}0.3810792 * * * \\
(0.1146524)\end{array}$ & $\begin{array}{l}0.275444^{* * *} \\
(0.0871562)\end{array}$ \\
\hline Formal education & $\begin{array}{c}0.0573637 \\
(0.1701313)\end{array}$ & $\begin{array}{c}0.5526512 \text { ** } \\
(0.2372697)\end{array}$ & $\begin{array}{l}0.26932 \text { ** } \\
(0.132962)\end{array}$ \\
\hline Member of farmers' organization & $\begin{array}{c}0.7012365^{* * * *} \\
(0.2163828)\end{array}$ & $\begin{array}{c}0.4330179 \\
(0.3008535)\end{array}$ & $\begin{array}{c}0.5835314^{* * * *} \\
(0.1726379)\end{array}$ \\
\hline Experience as farmers & $\begin{array}{c}0.0005645 \\
(0.0086495)\end{array}$ & $\begin{array}{c}0.0094195 \\
(0.0117617)\end{array}$ & $\begin{array}{c}0.0063591 \\
(0.0067245)\end{array}$ \\
\hline Relation with project/NGO & $\begin{array}{c}-0.2798718^{*} \\
(0.1510792)\end{array}$ & $\begin{array}{c}0.0128041 \\
(0.2069646)\end{array}$ & $\begin{array}{c}-0.2015533 * \\
(0.1177484)\end{array}$ \\
\hline Relation with extension services & $\begin{array}{c}0.5308142 * * * \\
(0.1667767)\end{array}$ & $\begin{array}{c}0.4660759 * * \\
(0.2346389)\end{array}$ & $\begin{array}{c}0.4868922 * * * * \\
(0.1326463)\end{array}$ \\
\hline Microfinance & $\begin{array}{c}0.3577431 \\
(0.3173143)\end{array}$ & $\begin{array}{c}0.0113474 \\
(0.3863392)\end{array}$ & $\begin{array}{c}0.2414714 \\
(0.2309711)\end{array}$ \\
\hline Mobile phone & $\begin{array}{l}-0.0259562 \\
(0.3436625)\end{array}$ & $\begin{array}{l}-0.0817045 \\
(0.2368866)\end{array}$ & $\begin{array}{c}-0.2101631 \\
(0.183789)\end{array}$ \\
\hline Radio & $\begin{array}{l}-0.0352541 \\
(0.1961114)\end{array}$ & $\begin{array}{c}0.6718186^{* *} \\
(0.3276947)\end{array}$ & $\begin{array}{c}0.2486221 \\
(0.1572521)\end{array}$ \\
\hline No. of crops & $\begin{array}{l}-0.0566698 \\
(0.0822458)\end{array}$ & $\begin{array}{c}0.1878422 \\
(0.1243009)\end{array}$ & $\begin{array}{c}0.068666 \\
(0.0638056)\end{array}$ \\
\hline Household size & $\begin{array}{l}-0.0001077 \\
(0.0083762)\end{array}$ & $\begin{array}{l}-0.0167238 \\
(0.0128195)\end{array}$ & $\begin{array}{l}-0.0072855 \\
(0.0069477)\end{array}$ \\
\hline Confident in Met Services & $\begin{array}{l}-0.0232625 \\
(0.1481973)\end{array}$ & $\begin{array}{c}0.0018982 \\
(0.1966192)\end{array}$ & $\begin{array}{l}-0.0185195 \\
(0.1151159)\end{array}$ \\
\hline Cultivated area & $\begin{array}{c}0.0062862 \\
(0.0104398)\end{array}$ & $\begin{array}{c}0.0737118^{* *} \\
(0.0344085)\end{array}$ & $\begin{array}{l}0.0151248 \\
(0.009668)\end{array}$ \\
\hline Constant & $\begin{array}{c}-2.001753 * * * * \\
(0.6677693)\end{array}$ & $\begin{array}{c}-3.567293 * * * \\
(0.7214265)\end{array}$ & $\begin{array}{c}-2.503482 \text { **** } \\
(0.4097876)\end{array}$ \\
\hline No. of observations & 614 & 418 & 1104 \\
\hline LR chi2(18) & 34.81 & 41.27 & 69 \\
\hline Prob $>$ chi 2 & 0.0016 & 0.0002 & 0 \\
\hline Pseudo R2 & 0.0777 & 0.1539 & 0.0941 \\
\hline
\end{tabular}

${ }^{* * *}=$ significant at $1 \%,{ }^{* *}=$ significant at $5 \%,{ }^{*}=$ significant at $10 \%($ ) standard error. 


\section{Discussion}

\subsection{Impact of the Use of SF on Crops and Income}

The results indicate that the use of SF can improve crop yields, especially for cereals such as rice, millet and maize, and thereby increase production. In doing so, it greatly contributes to achieving food security as, in Senegal in particular, the diet is largely dominated by cereals. The results also show that the use of SF has a significant effect on producers' incomes. Therefore, by increasing the production and farmers' incomes, the SF has become a good adaptation strategy for farmers in West Africa. Several researchers have proposed the use and application of SF as a tool for reducing risks of climate variability from a number of biophysical and social perspectives [18,51-53]. Similar results were found by several authors who used ex ante evaluation methods to determine the impact of the use of SF. Dabire et al. [54] has demonstrated that there is a slight income gain after the use of SF in rural areas in Burkina. Sultan et al. [14], through the analysis of previous studies, showed that farmers can achieve an increased income and risk reduction through the use of SF despite its uncertainty and imperfection. The results of the study confirmed those found by Lo and Dieng [19], who showed that the use of SF in Senegal increases the agricultural yields. Comparable results have been found also in South Africa by O'Brien et al. [26]. However, the SF cannot be valued without strategic decision-making in the context of production management. The benefit arises only through viable decision options that are sensitive to forecast information [55]. The accompanying operational decision might involve deciding which variety of crop to plant in order to achieve maximum yields [51]. In the framework of this study, the following decisions have been considered by men and women: the choice of early maturing variety, the sowing date, the ploughing period and the type of crop to grow. Similar studies $[18,25,26,41,56]$ have demonstrated the use of such adaptation strategies in response to seasonal forecasts. The study of O'Brien et al. [26] examines if and how farmers received, used and perceived the forecasts in the 1997/98 agricultural season in Namibia, South Africa and Tanzania. The results showed that farmers, in addition to the previous decisions, decide with the SF, the fertilizer spreading date and type and the choice of the crop location. Farmers from Niger chose in majority to change the sowing date and the type of crop following the reception of SF as mentioned by Tarhule and Lamb [56]. All these strategic decisions lead directly to improved crop yields.

\subsection{Gendered Impact of the Use of SF}

The results show that the use of SF gives different benefits according to sex. Several reasons can explain these differences. Firstly, men and women play different roles within particular systems of agricultural production and occupy different socioeconomic positions [1]. Traditionally, there is crop specialization by sex in rural areas in Senegal: women cultivate cereal crops called food crops while men focus mainly on cash crops. In the 2000s, Soumaré [57] showed that, in Senegal, women managed $56 \%$ of the total area of rice cultivation, $49 \%$ of the area under hibiscus (bissap) cultivation, $27 \%$ of the area under bean cultivation and $17 \%$ of the area under groundnut cultivation [27]. This means that women have little opportunity to change the type of crop when it is required after the reception of the SF. Secondly, women suffer from inequalities in terms of access to land and labor. They have smaller areas of land, which has resulted from historical social and legal barriers that have limited their access, their educational opportunities and their economic advancement in rural areas [27]. It is much easier for men to choose to cultivate on a given type of plot. As an example, depending on the season, it is sometimes more profitable to use varieties of rice at the level of the plateau. However, in these areas, most of the women do not have access to the plateau; their plots are in the lowlands. Thirdly, women also have limited access to credit and financial resources to enable them to make appropriate decisions. In fact, the decisions resulting from the seasonal forecast may be linked to the application or not of cropping operations (fertilization, weeding, application of pesticides) at defined periods and the lack of resources does not favor these operations. In addition to this, women are less adaptive because 
of financial or resource constraints because male domination in receiving information and extension services and because available adaptation strategies tend to create higher labor loads for women [3].

Moreover, the results show that the use of SF has a positive impact in particular on the yield of millet, sorghum, groundnut and rice for men and maize for women. Two main reasons can be considered. One is that women are the most involved in household food consumption and maize is a favored staple in the diet in rural areas in Senegal. Maize is the third most consumed cereal in rural areas, with an average of $19.5 \mathrm{~kg}$ per head per year. In the central-north region of the country and the south of the groundnut basin (main area of the survey), the consumption averages are significantly higher [58]. Thus, the price of the maize is quite competitive when compared to other crops. Given these facts, women can decide with regard to the behavior of the season to maximize their profit on maize to the detriment of other crops. As demonstrated, men with better access to productive resources can choose to maximize their profit by focusing one one or more speculations, as shown by our results.

\subsection{Determinants and Limits for the Uptake of SF}

The study indicates also that the following factors influence actively the use of seasonal forecast among women: the level of education, the ownership of a radio, the number of cultivated crops and the collaboration with extension services. Indeed, the level of education can influence the level of appropriation and understanding of climate information. As an example, an individual who has an advanced education level is more likely to understand and adopt the seasonal forecast. In sub-Saharan Africa, women are less likely than men to have a formal education. This can lead to misunderstanding of SF by women; as Jost et al. [3] showed in their study in Uganda, "Women did not seem to understand the seasonal forecast or its implication for agricultural decision-making, while men were able to do so". Concerning the extension services, sociocultural norms limit women's interactions with extension services that are in charge of agroclimatic training [59]. This reduces the chance of women to use effectively the SF. Besides, appropriate forecast use requires effective communication of relevant information [55]. The radio is the most used channel for WCIS dissemination. This explains why people who possess and listen regularly to the radio are likely to obtain weather information $[12,22,40,60]$. Among men, membership of farmers' organizations influences significantly the use of SF. Indeed, membership of a producers' organization is also an important factor that can improve the use of SF. Populations in rural areas identify themselves more with their social groups. This is why many authors have proposed using this group for the dissemination of new technologies. In the area of climate services in particular, Diouf et al. [40] suggested that to facilitate access to climate information services for relevant decision-making, it is essential to improve the capacity of farmers in WCIS use and to consider the producers' organizations as platforms for WCIS dissemination and training.

One of the major limitations of studies on seasonal forecasting is the impossibility of generalizing the results. The use of climate prediction by agriculture is still too new to support strong generalizations about its value [55]. The current study was carried out during the 2017-2018 agricultural season when the seasonal forecast was predicted to fall within the average status of the last 30-year rainy season ("normal"). A "normal" amount of rainfall is the middle third (tercile) of the average rainfall for the past number of years of rainfall data used to develop the forecast [51]. The results may be different if the season is above normal or below normal and if other decisions are made. Indeed, ex ante studies have shown that for the different forecast categories (dry year, wet year and normal year), the economic benefits are different. Sultan et al. [14] have shown that the economic value of using the seasonal forecast is much greater in a dry year. They found an added value of $80 \%$ profit in income compared to the situation without the use of seasonal forecasting. In Senegal in particular, they found that the expected profit was higher in wet years $(+12 \%)$ than in dry years $(+7 \%)$. This is because, in a wet year, the use of long-cycle varieties and fertilizers improves yields and these adjustments are less obvious in a dry year. This leads us to say that the impact observed in this current study may be higher if the forecast was dry season or wet season. Moreover, despite these observed differences in profits, it has been also demonstrated that the impact of the forecast error is lower if the year is normal, i.e., the 
economic cost of an error in the forecast is almost zero when the season is forecasted to be a normal season. Indeed, an error in the forecast may lead the farmer to make the wrong decisions. The type of decision to be made following the receipt of the seasonal forecast is therefore important because a farmer who chooses to grow a long-cycle variety when a short rainy season is forecast risks heavy losses. This is why it is important to make appropriate decisions for each type of forecast. Therefore, it is essential to strengthen the capacity of SF users for appropriate decision-making. In Senegal, the weather forecast is very often given during seminars organized by the National Met Service [7,12]. These seminars are an excellent framework for both male and female producers to express themselves but also to understand the most effective decisions to make during the crop year. Unfortunately, during these workshops, very few women are represented.

In many cases, even if the effects of weather information are considered very small, it is clear that the absence of this information further exposes farmers to the highest risks. Predicting a dry year in Senegal, for example, would avoid investing in crops with high production costs. As highlighted in this paper, the SF is beneficial for the improvement of crop production in the context of climate change but there is little uptake and use for both women and men.

\section{Conclusions}

The seasonal forecast is found to be one of the best adaptation strategies for rural populations whose farming activities depend mainly on rainfall patterns. This study assessed the gendered impact of the use of SF on the yield of main cereal crops and on agricultural income in a rural community in Senegal. It was demonstrated that farmers have an additional yield for millet, sorghum and rice and an additional gain in their net income. This revealed that the seasonal forecast significantly improves the productivity and farmer's income and therefore enhances food security, particularly when appropriate decisions are taken for crop production. The study also showed that the impact was higher within male farmers than within female farmers. Male potential adopters of SF have a higher surplus of production in millet, sorghum and rice, whereas female potential adopters have a higher surplus uniquely of rice. Thus, the use of SF benefits men and women differently. This is explained by the limited access of women to productive resources such as land, credit, inputs, etc., which reduce their capacity to quickly take appropriate decisions after the reception of SF. The low access to information is also a key constraint for women. It appears that closing the gender gap in agriculture is essential for the promotion of any resilient technologies.

Considering these findings, we recommend policies to extend the access to SF in rural areas, particularly among women. The dissemination through training and awareness raising should be promoted to allow social groups to make good use of it by making appropriate decisions. Selective targeting should be applied for women during the process of dissemination. Women's associations should be targeted. In addition, institutional policies are needed for sustained use of seasonal forecast. Indeed, the study showed that the impact of the use of SF is lower for female farmers due to inequalities in rural areas. So, to improve women's access to and use of SF, it is primordial to facilitate their access to land, inputs and financial resources. Land access policies must be revised for women and funding schemes established for them. Subsidy policies should be targeted primarily at female farmers. These measures will help to sustain the access to and use of SF and reinforce the resilience of rural communities, particularly female farmers.

Author Contributions: N.S.D., M.O., I.O. and G.A. designed, performed the data collection and analyzed them. N.S.D., M.O., I.O., R.Z. and G.A. wrote the paper. All authors have read and agreed to the published version of the manuscript.

Funding: This research received no external funding.

Acknowledgments: The authors acknowledge the USAID funding support to the CINSERE project in Senegal and we are thankful to the IPAR for data collection and the community (fisherfolk and key informants) for their collaboration. USAID/CINSERE project is implemented through ICRISAT by the CGIAR Research Program on Climate Change, Agriculture and Food Security (CCAFS), a strategic partnership of CGIAR and Future Earth, led by the International Center for Tropical Agriculture (CIAT) and carried out with support from CGIAR Fund 
Donors and through bilateral funding agreements (for details, please visit https://ccafs.cgiar.org/donors). We would like to express our deepest gratitude to the technicians of ANACIM who carried out the training on the ground.

Conflicts of Interest: The authors declare no conflict of interest.

\section{References}

1. Carr, E.R.; Fleming, G.; Kalala, T. Understanding Women's Needs for Weather and Climate Information in Agrarian Settings: The Case of Ngetou Maleck, Senegal. Weather Clim. Soc. 2016, 8, 247-264. [CrossRef]

2. Duong, M.T.; Smith, A.; Le, T.T.; Simelton, E.; Coulier, M. Gender-Differences in Agro-Climate Information Services (Findings from ACIS Baseline Survey in Ha Tinh and Dien Bien Provinces, Vietnam); CCAFS Info Note; CGIAR Research Program on Climate Change, Agriculture and Food Security (CCAFS): Wageningen, The Netherlands, 2017.

3. Jost, C.; Kyazze, F.; Naab, J.; Neelormi, S.; Kinyangi, J.; Zougmore, R.; Aggarwal, P.; Bhatta, G.; Chaudhury, M.; Tapio-Bistrom, M.-L; et al. Understanding gender dimensions of agriculture and climate change in smallholder farming communities. Clim. Dev. 2016, 8, 133-144. [CrossRef]

4. Partey, S.T.; Dakorah, A.D.; Zougmoré, R.B.; Ouédraogo, M.; Nyasimi, M.; Nikoi, G.K.; Huyer, S. Gender and climate risk management: Evidence of climate information use in Ghana. Clim. Chang. 2018, 158, 61-75. [CrossRef]

5. Adams, M.R.; Hurd, H.B.; Lenhart, S.; Leary, N. Effects of global climate change on agriculture: An interpretative review. Clim. Res. 1998, 11, 19-30. [CrossRef]

6. Gregory, P.J.; Ingram, J.S.I.; Brklacich, M. Climate change and food security. Phil. Trans. R. Soc. 2005, 360, 2139-2148. [CrossRef] [PubMed]

7. Roudier, P.; Sultan, B.; Quirion, P.; Berg, A. The impact of future climate change on West African crop yields: What does the recent literature say? Glob. Environ. Chang. 2011, 21, 1073-1083. [CrossRef]

8. Eltayeb, M.M. The Climate Change Impact on Crop Yield in Sub-Saharan African Countries Production Function Approach; Howard University: Washington, DC, USA, 2017.

9. Blanc, E. The Impact of Climate Change on Crop Yields in Sub-Saharan Africa. Am. J. Clim. Chang. 2012, 1, 1-13. [CrossRef]

10. Jalloh, A.; Nelson, G.C.; Thomas, S.T.; Zougmore, R.; Roy-Macauley, H. West African Agriculture and Climate Change: A Comprehensive Analysis; International Food Policy Research Institute: Washington, DC, USA, 2013. [CrossRef]

11. FAOSTAT. Base de Données Statistiques de la FAO. Disponible à L'adresse Suivante: Faostat.Fao.org.; FAOSTAT: Rome, Italy, 2005.

12. Ouedraogo, I.; Diouf, N.S.; Ouédraogo, M.; Ndiaye, O.; Zougmoré, R. Closing the Gap between Climate Information Producers and Users: Assessment of Needs and Uptake in Senegal. Climate 2018, 6, 13. [CrossRef]

13. Roudier, P.; Muller, B.; d'Aquino, P.; Roncoli, C.; Soumaré, M.A.; Batté, L.; Sultan, B. The role of climate forecasts in smallholder agriculture: Lessons from participatory research in two communities in Senegal. Clim. Risk Manag. 2014, 2, 42-55. [CrossRef]

14. Sultan, B.; Roudier, P.; Quirion, P. Les bénéfices de la prévision saisonnière pour l'agriculture en Afrique de l'Ouest. Sécheresse 2013, 24, 304-313. [CrossRef]

15. Roncoli, C.; Ingram, K.; Kirshen, P. Reading the Rains: Local Knowledge and Rainfall Forecasting in Burkina Faso. Soc. Nat. Resour. 2002, 15, 409-427. [CrossRef]

16. Klopper, E. The use of seasonal forecasts in South Africa during the 1997/98 rainfall season. Water SA 1999, 25, 311-316.

17. Rauch, M.; Bliefernicht, J.; Laux, P.; Salack, S.; Waongo, M.; Kunstmann, H. Seasonal Forecasting of the Onset of the Rainy Season in West Africa. Atmosphere 2019, 10, 528. [CrossRef]

18. Vogel, C.; O'Brien, K. Who can eat information? Examining the effectiveness of seasonal climate forecasts and regional climate-risk management strategies. Clim. Res. 2006, 33, 111-122. [CrossRef]

19. Lo, H.M.; Dieng, M. Impact Assessment of Communicating Seasonal Climate Forecasts in Kaffrine; Final Report for CCAFS West Africa Regional Program; Thies and Fatick (Niakhar) Regions in Senegal: Diourbel, Senegal; Louga, Senegal, 2015; p. 70. 
20. Meza, F.J.; Hansen, J.W.; Osgood, D. Economic Value of Seasonal Climate Forecasts for Agriculture: Review of Ex-Ante Assessments and Recommendations for Future Research. J. Appl. Meteorol. Clim. 2008, 47, 1269-1286. [CrossRef]

21. Ndeye Seynabou, D.; Leclerc, G.; Barbie, B.; Fall, S. The impact of seasonal forecast on farmer's strategic choices in the lake Guiers area in northern Senegal. IOP Conf. Ser. Earth Environ. Sci. 2009, 6, 392018.

22. Ochieng, R.; Recha, C.; Bebe, B.O. Enabling Conditions for Improved Use of Seasonal Climate Forecast in Arid and Semi-Arid Baringo County-Kenya. Open Access Libr. J. 2017, 4, 1-15. [CrossRef]

23. Hansen, J.W.; Mason, S.J.; Sun, L.; Tall, A. Review of seasonal climate forecasting for agriculture in sub-saharan africa. Exp. Agric. 2011, 47, 205-240. [CrossRef]

24. Rao, K.P.C.; Hansen, J.; Njiru, E.; Githungo, W.N.; Oyoo, A. Impacts of Seasonal Climate Communication Strategies on Farm Management and Livelihoods in Wote, Kenya; CCAFS Working Paper 42; CGIAR Research Program on Climate Change, Agriculture and Food Security (CCAFS): Wageningen, The Netherlands, 2015.

25. Blench, R. Forecasts and farmers: Exploring the limitations. In Coping with Climate Variability: The Use of Seasonal Climate Forecasts in Southern Africa; O’Brien, K., Vogel, C., Eds.; Ashgate: Aldershot, UK, 2003; pp. 59-71.

26. O'Brien, K.; Sygna, L.; Næss, L.; Kingamkono, R.; Hochobeb, B. Is Information Enough? User Responses to Seasonal Climate Forecasts in Southern Africa; Report 2000: 03; CICERO: Oslo, Norway, 2000.

27. USAID. Gender Issues and Agriculture in Senegal; USAID: Washington, DC, USA, 2010.

28. Null, N. The State of Food and Agriculture 2010-2011: Women in Agriculture, Closing the Gender Gap for Development; FAO: Rome, Italy, 2011.

29. McOmber, C.; Panikowski, A.; McKune, S.L.; Bartels, W.-L.; Russo, S. Investigating Climate Information Services through a Gendered Lens; CCAFS Working Paper no. 42; CGIAR Research Program on Climate Change, Agriculture and Food Security (CCAFS): Copenhagen, Denmark, 2013; p. 51. Available online: www.ccafs.cgiar.org (accessed on 22 February 2018).

30. Rubin, D.B. Estimating Causal Effects of Treatments in Randomized and Non-randomized Studies. J. Educ. Psychol. 1974, 66, 688-701. [CrossRef]

31. Sianesi, B. An Evaluation of the Swedish System of Active Labour Market Programs in the 1990s. Rev. Econ. Stat. 2004, 86, 133-155. [CrossRef]

32. Imbens, G.W.; Rubin, D.B. Causal Inference for Statistics, Social, and Biomedical Sciences: An Introduction; Cambridge University Press: Cambridge, UK, 2015.

33. Imbens, G.W.; Rubin, D.B. Estimating Outcome Distributions for Compliers in Instrumental Variable Models. Rev. Econ. Stud. 1997, 64, 555-574. [CrossRef]

34. Abadie, A. Semi-parametric Instrumental Variable Estimation of Treatment Response Models. J. Econ. 2003, 113, 231-263. [CrossRef]

35. Imbens, G.; Angrist, J. Identification and estimation of local average treatment effects. Econometrica 1994, 62, 467-475. [CrossRef]

36. Heckman, J.J.; Vytlacil, E.J. Structural Equations, Treatment effects and Econometric Policy Evaluation. Econometrica 2005, 72, 669-738. [CrossRef]

37. Rosenbaum, P.R.; Rubin, D.B. The central role of the propensity score in observational studies for causal effects. Biometrika 1983, 70, 41-55. [CrossRef]

38. Lee, M.J. Micro-Econometrics for Policy, Program and Treatment Effects. Advanced Texts in Econometrics; Oxford University Press: Oxford, UK, 2005.

39. Amegnaglo, C.J.; Anaman, K.A.; Mensah-Bonsu, A.; Onumah, E.E.; Amoussouga Gero, F. Contingent valuation study of the benefits of seasonal climate forecasts for maize farmers in the Republic of Benin, West Africa. Clim. Serv. 2017, 6, 1-11. [CrossRef]

40. Diouf, N.S.; Ouedraogo, I.; Zougmoré, R.; Ouedraogo, M.; Partey, S.T.; Gumucio, T. Factors influencing gendered access to climate information services for farming in Senegal. Gend. Technol. Dev. 2019, 23, 93-110. [CrossRef]

41. Ingram, T.K.; Roncoli, C.; Kirshen, P. Opportunities and constraints for farmers of west Africa to use seasonal precipitation forecasts with Burkina Faso as a case study. Agric. Syst. 2002, 74, 331-349. [CrossRef]

42. Cherotich, V.K.; Saidu, O.; Omedo, B.B. Access to climate change information and support services by the vulnerable groups in semi-arid Kenya for adaptive capacity development. Afr. Crop Sci. J. 2012, 20, 12. 
43. Ouédraogo, M.; Barry, S.; Zougmoré, R.; Partey, S.; Somé, L.; Baki, G. Farmers' Willingness to Pay for Climate Information Services: Evidence from Cowpea and Sesame Producers in Northern Burkina Faso. Sustainability 2018, 10, 611. [CrossRef]

44. Abebaw, D.; Haile, M.G. The impact of cooperatives on agricultural technology adoption: Empirical evidence from Ethiopia. Food Policy 2013, 38, 82-91. [CrossRef]

45. Ouédraogo, M.; Houessionon, P.; Zougmoré, R.B.; Partey, S.T. Uptake of Climate-Smart Agricultural Technologies and Practices: Actual and Potential Adoption Rates in the Climate-Smart Village Site of Mali. Sustainability 2019, 11, 4710. [CrossRef]

46. Diagne, A.; Midingoyi, S.G.; Kinkingninhoun-Medagbe, F.M. Impact of NERICA Adoption on Rice Yield: Evidence from West Africa. In An African Green Revolution; Otsuka, K., Larson, D., Eds.; Springer: Dordrecht, The Netherlands, 2013.

47. Cunguara, B.; Darnhofer, I. Assessing the impact of improved agricultural technologies on household income in rural Mozambique. Food Policy 2011, 36, 378-390. [CrossRef]

48. FAO. Countrystat. Available online: http://senegal.countrystat.org/ (accessed on 24 June 2020).

49. CIAT; BFS/USAID. Climate-Smart Agriculture in Senegal. CSA Country Profiles for Africa Series; International Center for Tropical Agriculture (CIAT); Bureau for Food Security, United States Agency for International Development (BFS/USAID): Washington, DC, USA, 2016.

50. FAO. FAOSTAT Senegal. 2016. Available online: http://faostat3.fao.org/home/E2016 (accessed on 1 June 2020).

51. Ziervogel, G.; Opere, A. Integrating meteorological and indigenous knowledge-based seasonal climate forecasts in the agricultural sector: Lessons from participatory action research in sub-Saharan Africa. Clim. Chang. Adapt. Afr. Learn. Pap. Ser. 2010, 1, 1-24.

52. Lemos, M.C.; Dilling, L. Equity in forecasting climate: Can science save the world's poor? Sci. Public Policy 2007, 34, 109-116. [CrossRef]

53. Patt, A.; Suarez, P.; Gwata, C. Effects of seasonal climate forecasts and participatory workshops among subsistence farmers in Zimbabwe. Proc. Natl. Acad. Sci. USA 2005, 102, 12623. [CrossRef]

54. Dabire, W.P.I.; Barbier, B.; Andrieu, N. Evaluation ex ante de la prévision saisonnière climatique en petit paysannat burkinabé. Revue d'Elevage et de Médecine Vétérinaire des Pays Tropicaux 2011, 64, 43. [CrossRef]

55. Hansen, J.W. Realizing the potential benefits of climate prediction to agriculture: Issues, approaches, challenges. Agric. Syst. 2002, 74, 309-330. [CrossRef]

56. Tarhule, A.; Lamb, P.J. Climate Research and Seasonal Forecasting for West Africans: Perceptions, Dissemination, and Use?: Perceptions, Dissemination, and Use? Bull. Am. Meteorol. Soc. 2003, 84, 1741-1760. [CrossRef]

57. Soumaré, H. The Integration of Gender Concerns into Agricultural Censuses: A case study of Senegal. In Agricultural Census and Gender: Lessons Learned in Africa; FAO: Rome, Italy, 2005.

58. Niang, M.; Seydi, B.; Hathie, I. Etude de la Consommation des Céréales de Base au Sénégal. Feed the Future Naatal Mbay-USAID; IPAR: Menlo Park, CA, USA, 2017; p. 128.

59. Gumucio, T.; Hansen, J.; Huyer, S.; Huysen, V.T.; Schwager, S. Identifying Pathways for More Gender-Sensitive Communication Channels in Climate Services; Info Note; CCAFS: Copenhagen, Denmark, 2018.

60. Zongo, B.; Diarra, A.; Barbier, B.; Zorom, M.; Yacouba, H.; Dogot, T. Farmers' Perception and Willingness to Pay for Climate Information in Burkina Faso. J. Agric. Sci. 2015, 8, 175. [CrossRef]

Publisher's Note: MDPI stays neutral with regard to jurisdictional claims in published maps and institutional affiliations.

(C) 2020 by the authors. Licensee MDPI, Basel, Switzerland. This article is an open access article distributed under the terms and conditions of the Creative Commons Attribution (CC BY) license (http://creativecommons.org/licenses/by/4.0/). 